\title{
Neerwaartse beroepsmobiliteit en arbeidsduurvermindering onder ouderen
}

\author{
Mark Visser, Maurice Gesthuizen, Gerbert Kraaykamp \& Maarten H.J. Wolbers*
}

Op basis van gangbare arbeidsmarkttheorieën verwachten we in deze studie dat werknemers van 50 jaar en ouder die zich in lagere sociale klassen bevinden, een grotere kans hebben op neerwaartse beroepsmobiliteit en een werkurenvermindering in hun late beroepsloopbaan dan oudere werknemers die tot hogere sociale klassen behoren. Om deze hypothese te toetsen wordt gebruikgemaakt van retrospectieve loopbaangegevens afkomstig van vier jaargangen (1998, 2000, 2003 en 2009) van de Familie-enquête Nederlandse Bevolking (FNB). Een gebeurtenissenanalyse toont aan dat oudere werknemers in lagere sociale klassen inderdaad vaker een stap terug (moeten) doen in termen van beroepsstatus en arbeidsuren. De bevindingen bevestigen de hypothese over de invloed van sociale klasse op beide gebeurtenissen onder oudere werknemers in Nederland. Geconcludeerd wordt dat de sociale ongelijkheid tussen ouderen toeneemt in de context van de vergrijzing.

\section{Introductie}

In veel westerse landen, waaronder Nederland, vormen de toenemende vergrijzing en krimpende beroepsbevolking een bedreiging voor de betaalbaarheid van het pensioenstelsel. Om de druk op de collectieve oudedagsvoorziening te verlichten en om ervaren ouder personeel te behouden, legt het huidige beleid in veel Europese landen zich toe op langer doorwerken (Foster \& Walker, 2015). De meest getroffen maatregelen zijn het verhogen van de pensioengerechtigde leeftijd en het afschaffen van regelingen voor vervroegde uittreding. Deze maatregelen lijken effect te hebben in Nederland. Oudere werknemers zijn namelijk in grotere getale werkzaam en gaan gemiddeld genomen op latere leeftijd met pensioen (CBS, 2016). Een belangrijke vraag is echter in hoeverre ouderen in staat zijn actief te blijven op de arbeidsmarkt en in hoeverre zij problemen ervaren om langer door te werken. De sociale ongelijkheid onder ouderen zou kunnen toenemen als gevolg van de beleidswijzigingen (Anxo et al., 2012; Visser, 2017). Voor kwetsbare groepen oudere werknemers, zoals lager opgeleide ouderen in lagere sociale klassen, is langer doorwerken wellicht onrealistisch.

Zo heeft stratificatieonderzoek aangetoond dat er aanzienlijke sociale verschillen bestaan in pensioenleeftijd (Blossfeld et al, 2011; Radl, 2013). Belangrijker nog, oudere mensen in lagere sociale klassen stoppen vaker noodgedwongen vroegtijdig met werken (Ebbinghaus \& Radl, 2015; Visser et al., 2016). Relatief weinig wetenschappelijk onderzoek heeft aandacht besteed aan arbeidsmarktervaringen

* Alle auteurs zijn werkzaam bij de Sectie Sociologie aan de Radboud Universiteit Nijmegen. E-mail: m.visser@maw.ru.nl. 
van ouderen vóór hun pensioen en aan sociale ongelijkheid in deze ervaringen. Naast onvrijwillige vervroegde uittreding kunnen kwetsbare werknemers ook teruggaan naar een lagere functie of minder uren gaan werken in hun late beroepsloopbaan. Dit onderzoek gaat na wat de invloed is van de sociale klasse van oudere werknemers op hun kans op neerwaartse beroepsmobiliteit en een urenvermindering. Op basis van de menselijk kapitaal-, signalerings- en arbeidsmarktsegmentatietheorie, en vanuit zowel werkgevers- als werknemersperspectief, beargumenteren we dat ouderen in lagere sociale klassen een grotere kans hebben een stap terug te (moeten) doen in termen van beroepsstatus en werkuren dan ouderen die tot hogere sociale klassen behoren. Als blijkt dat lagere sociale klassen inderdaad worden benadeeld in hun late beroepscarrière, dan duidt dit op sociale ongelijkheid. Aangezien het aantal ouderen dat actief is op de arbeidsmarkt alsmaar groeit, kan dit meer en meer ouderen treffen.

Een belangrijke overweging is of een stap terugdoen vrijwillig dan wel onvrijwillig is. Vanuit het oogpunt van de werknemer hebben vrijwillige functiewijzigingen uiteraard de voorkeur. Werkgevers lijken voornamelijk geïnteresseerd in beleid dat oudere werknemers ontziet (te denken valt aan deeltijdpensionering, het verstrekken van extra verlof of het verminderen van de werklast) in plaats van maatregelen die de inzetbaarheid en productiviteit van hun oudere personeelsbestand kunnen verbeteren (Conen et al., 2011; Van Dalen et al., 2009). Een veel geopperde strategie is demotie van oudere werknemers. Demotie verwijst naar een teruggang in positie en loon oftewel neerwaartse beroepsmobiliteit met een loonsverlaging. Demotie heeft een negatieve connotatie, omdat het een zekere mate van gedwongenheid suggereert. Veel werkgevers zijn van mening dat productiviteit afneemt met leeftijd (Van Dalen et al., 2010b) en demotie is dan een instrument om het salaris aan te passen aan de (verwachte) productiviteit. Dit zal in het bijzonder opgaan voor ouderen in lagere sociale klassen.

Hoewel werkgevers in Europa demotie van oudere werknemers vaak overwegen, passen zij het zelden toe (Van Dalen \& Henkens, 2014; 2015). In Nederland beschouwt vier op de tien werkgevers demotie als een reële optie (Van Dalen et al., 2010a), terwijl slechts 7\% het daadwerkelijk heeft toegepast in 2013 (SCP, 2015). Managers aarzelen om demotiebeleid concreet te maken vanwege de negatieve gevolgen voor de motivatie van hun werknemers (Van Dalen \& Henkens, 2013). Men maakt zich niet alleen zorgen over de motivatie van de teruggeplaatste werknemer, die wellicht te maken krijgt met stigmatisering, maar ook dat het een negatieve invloed heeft op de gehele onderneming (Carson \& Carson, 2007; Groot, 1997). Wanneer Nederlandse oudere werknemers zelf wordt gevraagd naar hun mening, blijken zij demotie paradoxaal genoeg te zien als een kans om werktevredenheid te herwinnen, om het rustiger aan te doen in hun late beroepsloopbaan of om de overgang van werk naar pensioen soepeler te laten verlopen (Jongsma, 2014). Een recente studie toont aan dat $60 \%$ van de ouderen zich kan voorstellen een lager betaalde functie te aanvaarden (Van Dalen \& Henkens, 2015). Hoger opgeleide ouderen geven veelal aan dat een minder stressvolle baan aantrekkelijk zou zijn, terwijl hun lager opgeleide collega's vaker reductie van de werklast als reden opgeven.

Empirisch onderzoek naar de oorzaken en gevolgen van demotie van oudere werknemers is schaars en vooral beschrijvend (Van Dalen \& Henkens, 2014; 2015). Demotie lijkt niet erg effectief te zijn als het gaat om het verhogen van 
de baantevredenheid en motivatie onder oudere werknemers (Josten \& Schalk, 2010). Werknemers blijken doorgaans zelfs minder tevreden met hun baan en tevens minder gemotiveerd na demotie (Josten \& Schalk, 2016). Een mogelijke verklaring voor deze bevinding is dat demotie vaak onvrijwillig is door bijvoorbeeld een arbeidsconflict of reorganisatie. Bedrijven die erin slagen om demotie op een juiste wijze toe te passen, zijn echter beter in staat oudere werknemers te behouden en in te zetten (Oude Mulders et al., 2015). Kijkend naar de determinanten van demotie blijkt een slechte gezondheid een belangrijke voorspeller te zijn (Josten \& Schalk, 2016). Ook minder gemotiveerde medewerkers en personeel dat niet bereid is om deel te nemen aan opleidingsactiviteiten, blijken een verhoogd risico op demotie te lopen (Van Dalen \& Henkens, 2014). Deze studie draagt bij aan eerder onderzoek door dieper in te gaan op neerwaartse beroepsmobiliteit onder oudere werknemers in Nederland. Slechts $4 \%$ van de cao's biedt de mogelijkheid tot een teruggang in functie gepaard met een loonsverlaging. Neerwaartse beroepsmobiliteit - een teruggang in beroep met behoud van salaris - is mogelijk in 30\% van de cao's (Smits et al., 2010). Daarnaast genieten oudere werknemers in Nederland strikte ontslagbescherming en worden ze over het algemeen betaald op basis van anciënniteit en senioriteit. Een salarisverlaging is kortom zeer onwaarschijnlijk in de Nederlandse context. We achten het daarom redelijk om in deze studie te verwijzen naar neerwaartse beroepsmobiliteit en niet naar demotie, temeer omdat onze meting van neerwaartse beroepsmobiliteit gebaseerd is op de beroepsstatusschaal van Ganzeboom et al. (1992). ${ }^{1}$

Deze studie gaat tevens dieper in op arbeidsduurvermindering onder ouderen op de Nederlandse arbeidsmarkt. Minder uren gaan werken kan voor oudere werknemers een manier zijn om langer actief te blijven op de arbeidsmarkt. Ook heeft men zo meer tijd voor recreatie, kleinkinderen of vrijwilligerswerk. Dit impliceert dat een urenvermindering een vrijwilliger karakter heeft vergeleken met neerwaartse beroepsmobiliteit, maar dit is niet per definitie het geval. Het terugbrengen van het aantal werkuren kan namelijk ook het gevolg zijn van bijvoorbeeld een fysiek veeleisende baan of een slechte gezondheid. Een urenvermindering kan dus net zo goed gedwongen zijn.

Verder kan neerwaartse beroepsmobiliteit samenvallen met een urenvermindering en beide gebeurtenissen kunnen vergelijkbare oorzaken hebben. Onze interesse gaat specifiek uit naar de invloed van sociale klasse, omdat dit belangrijke inzichten kan opleveren over de oorzaken van sociale ongelijkheid in de late beroepscarrière. Onze onderzoeksvraag luidt: In hoeverre beïnvloedt de sociale klasse van oudere werknemers in Nederland hun kans op neerwaartse beroepsmobiliteit en werkurenvermindering? We richten ons op mannen van 50 jaar en ouder, omdat de arbeidsdeelname van oudere vrouwen (te) laag is in de geboortecohorten die we bestuderen. We maken gebruik van retrospectieve loopbaangegevens afkomstig van vier jaargangen (1998, 2000, 2003 en 2009) van de Familie-enquête Nederlandse Bevolking (FNB) en passen hierop gebeurtenissenanalyse toe om de invloed van sociale klasse te schatten rekening houdend met opleidingsniveau, arbeidsverleden, partnerkenmerken en macro-economische omstandigheden. 


\section{De invloed van sociale klasse}

Gebaseerd op gevestigde arbeidsmarkttheorieën, met name de menselijk kapitaal-, signalerings- en arbeidsmarktsegmentatietheorie, verwachten we dat oudere werknemers in lagere sociale klassen vaker neerwaarts mobiel zijn en minder uren gaan werken dan oudere werknemers in hogere sociale klassen. We beargumenteren vanuit deze theorieën dat oudere werknemers in lagere sociale klassen minder productief zijn, negatieve signalen afgeven aan werkgevers en vaker werkzaam zijn in het secundaire segment van de arbeidsmarkt. Sociale klasse verwijst hierbij naar het huidige beroep van ouderen.

De menselijk kapitaaltheorie stelt dat personen kunnen investeren in hun menselijk kapitaal door diploma's te halen, deel te nemen aan cursussen en werkervaring op te bouwen. Personen met meer menselijk kapitaal zijn productiever (in de ogen van werkgevers) en dit leidt tot betere baankansen en hogere beloningen (Becker, 1964). Bekend is ook dat personen met een hoger opleidingsniveau vaker terechtkomen in hogere sociale klassen dan personen met lagere opleidingsniveaus (Erikson \& Goldthorpe, 1992). Het menselijk kapitaal van oudere werknemers kan onderhevig zijn aan depreciatie, al hangt dit sterkt af van onder andere de arbeidsomstandigheden, het beroepsverleden en de werkgelegenheid. Zo kan kennis verouderd zijn en kunnen vaardigheden overbodig zijn geworden in een sterk veranderende arbeidsmarkt. Ofschoon ouderen veel werkervaring hebben en bedrijfsspecifieke kennis hebben vergaard, vinden werkgevers dat ouderen minder flexibel zijn en over minder technische vaardigheden beschikken dan jongere werknemers (Conen et al., 2012). Al eerder kwam aan bod dat lagere sociale klassen en met name (hand)arbeiders in de industriesector moeite hebben met langer doorwerken (Visser et al., 2016). Meer algemeen verwachten we dat oudere werknemers in lagere sociale klassen minder productief zijn of als minder productief worden ingeschat door werkgevers. Een lagere (verwachte) productiviteit geeft tevens een negatief signaal af aan werkgevers (Spence, 1973). Het menselijk kapitaal van ouderen die tot lagere sociale klassen behoren, veroudert mogelijk ook sneller en het kan voor hen lastig zijn hun menselijk kapitaal op peil te houden of zich aan te passen aan veranderende arbeidsmarktomstandigheden.

Een daling van productiviteit veroorzaakt door verouderd menselijk kapitaal zou in theorie moeten leiden tot een lager loon, maar in de praktijk komt dit zelden voor. Werkgevers houden geen salaris in wanneer de productiviteit van oudere werknemers afneemt. Deels komt dit doordat de oudere beroepsbevolking een belangrijke rol speelt in collectieve arbeidsonderhandelingen en wordt beschermd door strenge regelgeving omtrent demotie en ontslag. Volgens Lazear (1979) hebben werkgevers een impliciete overeenkomst met hun werknemers. Het idee is dat lonen aan het begin van de arbeidscarrière beneden de feitelijke arbeidsproductiviteit liggen, terwijl de lonen aan het eind van de loopbaan juist hoger zijn dan de productiviteit. Deze overeenkomst gaat alleen op wanneer werknemers levenslang voor hetzelfde bedrijf blijven werken. Voor een groot gedeelte van de oudere mannen die we bestuderen, is dit nog het geval. De vergrijzing heeft een negatieve invloed op de houdbaarheid van dergelijke impliciete contracten, aangezien lonen op basis van anciënniteit een zware financiële last voor ondernemingen kunnen vormen. Werkgevers kunnen ingrijpen door rechtstreeks het 
onevenwicht tussen loon en productiviteit aan te pakken. Zo kan men het menselijk kapitaal en de productiviteit van oudere werknemers op peil houden of vergroten (bijvoorbeeld door cursussen aan te bieden), maar men kan ook overgaan tot een loonsverlaging. Neerwaartse beroepsmobiliteit en arbeidsduurverkorting behoren eveneens tot de mogelijkheden. Beide opties zouden tot een verhoogde productiviteit kunnen leiden, omdat oudere werknemers minder hoeven te werken en wellicht ook minder zwaar werk hoeven te verrichten, meer vrije tijd hebben en gemotiveerder raken. Met name lagere sociale klassen kunnen hier profijt van hebben, aangezien vooral zij op latere leeftijd te kampen kunnen krijgen met gezondheidsklachten en een daling in productiviteit.

Verder veronderstellen we dat ouderen in lagere sociale klassen vaker werkzaam zijn in het secundaire segment van de arbeidsmarkt. Volgens de arbeidsmarktsegmentatietheorie bestaat de arbeidsmarkt uit twee wezenlijk verschillende segmenten: een primair en een secundair segment (Piore, 1975). Banen in het primaire segment kenmerken zich door hogere status, hoger loon, vaste contracten, gunstige arbeidsvoorwaarden en promotiekansen. Banen in het secundaire segment kenmerken zich daarentegen door lagere status, lager loon, tijdelijke contracten, beperkte carrièremogelijkheden en minder bescherming (Kalleberg et al., 2000). Onze verwachting is dat oudere werknemers in lagere sociale klassen zich vaker bevinden in dit secundaire segment van de arbeidsmarkt en dat zij daardoor kwetsbaarder zijn voor (onvrijwillige) neerwaartse beroepsmobiliteit en urenvermindering. Het gaat bijvoorbeeld om zware beroepen die grotere gezondheidsrisico's met zich meebrengen en een productiviteitsdaling kunnen veroorzaken (Deaton \& Paxson, 1998). Ouderen die zwaar werk verrichten, kunnen op een gegeven moment simpelweg niet meer in staat zijn om hun werk te doen. Werkgevers zijn minder geneigd om te investeren in deze werknemers. Oudere werknemers in lagere sociale klassen hebben daarnaast minder autonomie, ze geven minder vaak leiding en de werkomstandigheden zijn vaak slechter, althans vergeleken met hogere sociale klassen (Erikson \& Goldthorpe, 1992). Met betrekking tot vrijwillige baanveranderingen kunnen zowel ouderen in hogere als in lagere sociale klassen een voorkeur hebben om een lagere functie te bekleden of minder uren te gaan werken, zij het om andere redenen. Voor lagere sociale klassen kan een vrijwillige stap terugdoen de enige manier blijken om actief te blijven op de arbeidsmarkt tot zij met pensioen kunnen. Ze hebben vaak zware beroepen die fysiek veeleisend zijn. Dit kan zorgen voor ontevredenheid met het werk en demotivatie. Het is bekend dat ontevredenheid over werkaspecten zoals het loon, de werkdruk of de baan in het algemeen vrijwillige beroepsmobiliteit veroorzaakt (Gesthuizen \& Dagevos, 2008; Sørensen, 1975). Oudere werknemers in lagere sociale klassen streven wellicht naar een minder belastende baan of in ieder geval naar een vermindering van het aantal werkuren. Een dergelijke preferentie kan ook onder oudere werknemers in hogere sociale klassen leven. Zij hebben vaker een stressvolle baan in termen van verantwoordelijkheid, aansturing en tijdsdruk (Erikson \& Goldthorpe, 1992). Overstappen naar een lagere functie of minder uren gaan werken kan die stress verminderen. Onvrede met bepaalde baankenmerken kan dus ook onder hogere beroepsgroepen leiden tot vrijwillige mobiliteit (Gesthuizen, 2009). Tegelijkertijd zullen oudere werknemers in hogere sociale klassen hun sociale status niet willen verliezen en 
wellicht ook meer intrinsiek gemotiveerd zijn om te werken dan ouderen in lagere sociale klassen (Gesthuizen \& Verbakel, 2011).

\section{Methode}

\section{Data}

Om onze hypothese over de invloed van sociale klasse te toetsen maken we gebruik van vier jaargangen (1998, 2000, 2003 en 2009) van de Familie-enquête Nederlandse Bevolking (FNB). De doelpopulatie bestaat uit Nederlandssprekende individuen in de leeftijd van 18 tot 70 jaar en hun partners, woonachtig in Nederland. Respondenten worden face-to-face geïnterviewd en gevraagd wordt onder meer naar hun complete arbeidsverleden. We beschikken over maandelijkse gegevens over de beroepstitel, beroepsstatus, sociale klasse, het aantal werkuren, enzovoort. De steekproeven zijn grotendeels representatief voor de Nederlandse bevolking. In iedere jaargang komen gehuwden en samenwonenden en daardoor ouderen vaker voor. Meer informatie over de dataverzameling, steekproeftrekking, responspercentages en vragenlijst is beschikbaar in de datadocumentatie (Kraaykamp et al., 2009).

De retrospectieve loopbaangegevens zijn gebruikt om een zogenoemd persoonmaandbestand te construeren. We hebben mannen van 50 jaar en ouder geselecteerd en alleen als zij op 50-jarige leeftijd werkzaam waren. Vanaf die leeftijd volgen wij deze mannen door hun loopbaan en lopen zij het 'risico' om neerwaartse beroepsmobiliteit en/of een urenvermindering mee te maken. De observatieperiode eindigt wanneer iemand een gebeurtenis ervaart, met vervroegd pension gaat of de toenmalige AOW-leeftijd van 65 jaar bereikt. Respondenten die geen gebeurtenis meemaken, zijn rechts gecensureerd. Gepensioneerden worden niet meegenomen in de analyse, omdat nagenoeg alle gepensioneerden in de data niet herintreden en dus geen 'risico' lopen. Zelfstandigen maken wel deel uit van de dataselectie. Zij kunnen te allen tijde een urenvermindering meemaken, maar ook neerwaartse beroepsmobiliteit wanneer zij (om welke reden dan ook) weer als werknemer bij een onderneming in dienst treden. ${ }^{2}$

\section{Afhankelijke variabelen}

Twee afhankelijke variabelen of gebeurtenissen staan centraal in deze studie. Neerwaartse beroepsmobiliteit is gedefinieerd als een daling van vijf punten op de ISEI-schaal (Ganzeboom et al., 1992) van de ene op de volgende maand. Een urenvermindering bestaat uit een daling van minimaal acht uur per week (het equivalent van een werkdag). Aangezien er bodemeffecten kunnen optreden, nemen we in de analyse alleen oudere mannen mee die kunnen dalen in de gespecificeerde aantallen. ISEI-scores van 16 tot en met 20 evenals werkuren van 1 tot en met 8 zijn daarom buiten de analyse gelaten. Dit heeft geleid tot twee licht verschillende steekproeven en daarom tot twee separate gebeurtenissenanalyses. ${ }^{3}$

\section{Onafhankelijke variabelen}

De belangrijkste onafhankelijke variabele in dit onderzoek is sociale klasse. Sociale klasse kan maandelijks variëren en is gebaseerd op het EGP-klassenschema 
(Erikson \& Goldthorpe, 1992). We onderscheiden zeven klassen: (I) hogere leidinggevenden, academici, (II) supervisors hoofdarbeid, hooggeschoolde hoofdarbeid, (III) geschoolde hoofdarbeid, half- en ongeschoolde hoofdarbeid, (IV) zelfstandigen, (V) supervisors handarbeid, hooggeschoolde handarbeid, (VI) geschoolde handarbeid, en (VII) halfgeschoolde en ongeschoolde handarbeid, agrarische arbeid. Deze klassen zijn gemeten vanaf het vijftigste levensjaar en ouder.

Om de invloed van sociale klasse zo zuiver mogelijk te schatten is het van belang om te controleren voor andere huidige beroepskenmerken, arbeidsverleden, opleidingsniveau, partnerkenmerken en macro-economische omstandigheden. We houden allereerst rekening met herintreding na werkloosheid of arbeidsongeschiktheid. Dit zijn twee afzonderlijke dummyvariabelen die als 1 gecodeerd zijn voor de maand (en alleen die maand) waarop respondenten weer werkzaam zijn. Het aantal werkuren bestaat uit de categorieën 1-34 uur (deeltijdwerk), 3540 uur, 41-50 uur en meer dan 50 uur. We voegen een aantal variabelen toe om het arbeidsverleden samen te vatten. Deze variabelen zijn gemeten voor het 50ste levensjaar. De analyse bevat de gemiddelde beroepsstatus (wederom op de ISEI-schaal), het aantal jaren dat iemand voltijd, deeltijd en als zelfstandige werkzaam is geweest, het aantal baanveranderingen, neer- en opwaartse beroepsmobiliteit tussen de 40 en 50 jaar, een daling en stijging van het aantal werkuren tussen de 40 en 50 jaar, en het aantal maal dat iemand werkloos en arbeidsongeschikt is geweest. Tot slot controleren we voor het hoogst behaalde opleidingsniveau en de in de tijd variërende factoren leeftijd, werkloosheidspercentage en arbeidsdeelname van de partner. In tabel 1 geven we beschrijvende informatie weer voor alle kenmerken. Het aantal persoon-maanden verschilt per afhankelijke variabele door de eerder toegepaste selecties en daardoor wijkt de beschrijvende informatie ook licht af.

\section{Analyse}

We maken gebruik van gebeurtenissenanalyse om de invloed van sociale klasse op de twee gebeurtenissen - neerwaartse beroepsmobiliteit en arbeidsduurvermindering - te schatten. Deze analysemethode biedt de kans om meer betrouwbare uitspraken te doen over causale relaties. Aangezien de afhankelijke variabelen uit twee categorieën bestaan (wel of geen gebeurtenis), gaat het hier om een logistische regressieanalyse uitgevoerd op het persoon-maandbestand. Het was niet mogelijk om beide uitkomstmaten gezamenlijk te analyseren vanwege het geringe aantal gebeurtenissen. ${ }^{4}$ Beide gebeurtenissen vallen soms ook samen, maar een categorische variabele aanmaken (bestaande uit de categorieën alleen neerwaarts mobiel, alleen een urenvermindering en beide tegelijkertijd) is problematisch gezien de verdeling van de onafhankelijke kenmerken en het bestaan van nulcellen. We voeren daarom twee separate gebeurtenissenanalyses uit voor de kans op neerwaartse mobiliteit ( 86 gebeurtenissen; $5,2 \%$ van de respondenten) en een urenvermindering ( 68 gebeurtenissen; $4,1 \%$ ) en presenteren zowel logits als gemiddelde marginale effecten. 
Tabel 1 Beschrijvende statistiek

\begin{tabular}{|c|c|c|c|c|c|}
\hline & \multirow[b]{2}{*}{ Bereik } & \multicolumn{2}{|c|}{$\begin{array}{l}\text { Neerwaartse } \\
\text { mobiliteit }\end{array}$} & \multicolumn{2}{|c|}{$\begin{array}{l}\text { Vermindering } \\
\text { van uren }\end{array}$} \\
\hline & & Gem. & SD & Gem. & SD \\
\hline \multicolumn{6}{|l|}{ Afhankelijke variabelen } \\
\hline Neerwaartse mobiliteit (86 keer) & $0 / 1$ &, 001 & & & \\
\hline Urenvermindering (68 keer) & $0 / 1$ & & & ,001 & \\
\hline \multicolumn{6}{|l|}{ Sociale klasse } \\
\hline 1 & $0 / 1$ &, 188 & & , 188 & \\
\hline II & $0 / I$ & ,237 & & 234 & \\
\hline III & $0 / 1$ &, 112 & &, 110 & \\
\hline IV & $0 / 1$ &, 072 & & ,072 & \\
\hline $\mathrm{V}$ & $0 / 1$ & ,091 & &, 090 & \\
\hline VI & $0 / 1$ &, 112 & &, 113 & \\
\hline VII & $0 / 1$ & 188 & & 192 & \\
\hline Herintreden na werkloosheid & $0 / 1$ &, 000 & &, 000 & \\
\hline Herintreden na arbeidsongeschiktheid & $0 / 1$ &, 000 & &, 000 & \\
\hline \multicolumn{6}{|l|}{ Aantal werkuren } \\
\hline I-34 uur (deeltijdwerk) & $0 / 1$ & ,063 & & ,048 & \\
\hline $35-40$ uur & $0 / 1$ & ,676 & & ,685 & \\
\hline $4 I-50$ uur & $0 / 1$ &, 134 & &, 137 & \\
\hline$>50$ uur & $0 / 1$ &, 127 & &, 130 & \\
\hline \multicolumn{6}{|l|}{ Arbeidshistorie } \\
\hline Gemiddelde beroepsstatus & $19-88$ & 47,800 & 13,719 & 47,649 & $|3,72|$ \\
\hline Aantal jaren voltijdwerk & $0-44$ & 29,809 & 6,580 & 29,917 & 6,499 \\
\hline Aantal jaren deeltijdwerk & $0-35$ & $\mathrm{I}, 0 \mathrm{II}$ & 4,353 & 0,961 & 4,266 \\
\hline Aantal jaren zelfstandig & $0-39$ & 2,967 & 8,351 & 3,013 & 8,422 \\
\hline Aantal baanveranderingen & $0-10$ & 1,642 & $\mathrm{I}, 887$ & 1,650 & 1,886 \\
\hline Neerwaartse mobiliteit (tussen $40-50$ jaar) & $0 / 1$ & 090 & & ,091 & \\
\hline Opwaartse mobiliteit (tussen 40-50 jaar) & $0 / 1$ &, 126 & &, 126 & \\
\hline Urenvermindering (tussen 40-50 jaar) & $0 / 1$ &, 050 & & ,046 & \\
\hline Urenvermeerdering (tussen $40-50$ jaar) & $0 / 1$ & ,066 & & ,064 & \\
\hline Aantal keer werkloos en arbeidsongeschikt & $0-3$ & 0,077 & 0,298 & 0,075 & 0,296 \\
\hline \multicolumn{6}{|l|}{ Opleidingsniveau } \\
\hline Primair & $0 / 1$ & ,357 & & ,358 & \\
\hline Lager secundair & $0 / 1$ &, 133 & &, 135 & \\
\hline Hoger secundair & $0 / 1$ &, 214 & &, 216 & \\
\hline Tertiair & $0 / 1$ & ,297 & & ,291 & \\
\hline Leeftijd & $50-65$ & 54,758 & 3,488 & 54,697 & 3,463 \\
\hline Werkloosheidspercentage & $\begin{array}{l}1,2- \\
10,7\end{array}$ & 6,086 & $|, 82|$ & 6,092 & $|, 82|$ \\
\hline \multicolumn{6}{|l|}{ Arbeidsdeelname partner } \\
\hline Partner werkzaam & $0 / 1$ & ,439 & & ,439 & \\
\hline Partner niet werkzaam & $0 / 1$ & ,440 & & ,440 & \\
\hline Geen partner & $0 / 1$ &, 121 & & , 120 & \\
\hline
\end{tabular}

Bron: FNB 1998, 2000, 2003 en 2009; $N_{\text {persoon-maanden }}=135.487 ; 132.400$ 


\section{Bevindingen}

Tabel 2 geeft de resultaten van beide gebeurtenissenanalyses weer. Onze hypothese over de invloed van sociale klasse op de kans om neerwaarts mobiel te zijn en minder uren te gaan werken wordt duidelijk bevestigd. We vinden sterke effecten van sociale klasse gecontroleerd voor een arsenaal aan relevante factoren, zoals opleidingsniveau, het arbeidsverleden, de arbeidsdeelname van de partner en de macro-economische omstandigheden. Oudere mannen die tot lagere sociale klassen behoren (in het bijzonder halfgeschoolde en ongeschoolde handarbeiders), hebben zowel een grotere kans om terug te gaan naar een lagere functie in termen van status als een grotere kans op arbeidsduurvermindering dan oudere mannen die tot hogere sociale klassen behoren (met name vergeleken met hogere leidinggevenden en academici). Kijkend naar de coëfficiënten zien we dat de hoogste sociale klasse (EGP I) de kleinste kans heeft om beide gebeurtenissen mee te maken ten opzichte van alle andere sociale klassen. Met andere woorden: het is zeer onwaarschijnlijk dat hogere leidinggevenden en academici neerwaartse beroepsmobiliteit en een urenvermindering ervaren in hun late arbeidscarrière vergeleken met lagere sociale klassen (EGP II tot en met EGP VII). Op basis van de gemiddelde marginale effecten hebben oudere handarbeiders de grootste kans op beide gebeurtenissen en lijkt er een bijna lineair verband te bestaan tussen sociale klasse en beide uitkomsten. Nogmaals: dit is in overeenstemming met onze hypothese.

We bespreken ook kort de resultaten met betrekking tot enkele controlevariabelen. Het vinden van een baan na werkloosheid of na arbeidsongeschiktheid is een sterke voorspeller van beide gebeurtenissen. Oudere mannen die herintreden na een periode werkloos of arbeidsongeschikt geweest te zijn, komen terecht in functies met een lagere beroepsstatus en minder uren dan voorheen (toen zij nog werkzaam waren). Allereerst gaat er een negatief signaal uit van werkloosheid en arbeidsongeschiktheid (Spence, 1973). Oudere werknemers die werkloos of arbeidsongeschikt zijn, kunnen door potentiële werkgevers bijvoorbeeld worden gezien als minder productief of incompetent. Werkloosheid en arbeidsgeschiktheid werken stigmatiserend en laten littekens na. Het is daarom onwaarschijnlijk dat oudere werkzoekenden aan de bak komen wanneer zij hoge looneisen stellen. $\mathrm{Zij}$ zullen genoegen moeten nemen met een lagere positie (en hoogstwaarschijnlijk ook met een lager salaris) en minder werkuren.

Verder stellen we vast dat deeltijdwerk (1-34 uur per week) een positief effect heeft op de kans op beide gebeurtenissen. Oudere mannen die minder dan 35 uur per week werken, zijn vaker neerwaarts mobiel en gaan vaker minder uren werken dan oudere mannen die voltijd werken (35-40 uur per week). Het is daarnaast interessant om te zien dat oudere mannen die meer dan 50 uur per week werkzaam zijn, een kleinere kans hebben op neerwaartse beroepsmobiliteit en arbeidsduurvermindering. Vooral de laatste bevinding kan onlogisch klinken, omdat deze mannen meer ruimte hebben voor een urenvermindering. We vermoeden dat het hier draait om een groep mannen die intrinsiek gemotiveerd is om te blijven werken, in goede gezondheid verkeert en niet zo snel geneigd is om het rustiger aan te doen in hun late beroepsloopbaan. Oudere werknemers in deeltijd zijn mogelijk minder gehecht aan de arbeidsmarkt en minder gemotiveerd (Tilly, 1996). 
Tabel 2 Resultaten logistische regressieanalyse van neerwaartse beroepsmobiliteit (-5 ISEI punten) en urenvermindering ( -8 uren), logits en gemiddelde marginale effecten

\begin{tabular}{|c|c|c|c|c|}
\hline & \multicolumn{2}{|c|}{ Neerwaartse mobiliteit } & \multicolumn{2}{|c|}{ Urenvermindering } \\
\hline & Logit & GME & Logit & GME \\
\hline \multicolumn{5}{|l|}{ Sociale klasse } \\
\hline $\mathrm{I}$ & ref. & ref. & ref. & ref. \\
\hline II & $1,892 * * *$ &, $001 * *$ & $2,031 * * *$ &, $001 * *$ \\
\hline III & $6,094 * * *$ &, $004 * * *$ & $2,158 * *$ &, $001 * *$ \\
\hline IV & $6,233 * * *$ &, $004 * * *$ & $2,194 *$ &, $001 *$ \\
\hline $\mathrm{V}$ & $3,905 * * *$ &, $002 * * *$ & $2,620 * *$ &, $001 * *$ \\
\hline VI & $7,628 * * *$ &, $004 * * *$ & $2,891 * *$ &, $001 * *$ \\
\hline VII & $8,575 * * *$ &, $005 * * *$ & $2,476 * *$ &, $001 *$ \\
\hline Herintreden na werkloosheid & $6,733 * * *$ &, $004 * * *$ & $4,796 * * *$ &, $002 * * *$ \\
\hline Herintreden na arbeidsongeschiktheid & $6,254 * * * *$ &, $004 * * *$ & $6,833 * * *$ &, $003 * * *$ \\
\hline \multicolumn{5}{|l|}{ Aantal werkuren } \\
\hline I-34 uur (deeltijdwerk) & $2,291 * * * *$ &, $001 * * *$ & $8,060 * * *$ &, $003 * * *$ \\
\hline $35-40$ uur & ref. & ref. & ref. & ref. \\
\hline $4 I-50$ uur & 0,587 &, 000 & $-0,972$ &, 000 \\
\hline$>50$ uur & $-1,129 *$ &,$- 001 *$ & $-2,087 *$ &,$- 001 *$ \\
\hline \multicolumn{5}{|l|}{ Arbeidshistorie } \\
\hline Gemiddelde beroepsstatus & $0,218 * * * *$ &, $000 * * *$ & $0,055 *$ &, $000 *$ \\
\hline Aantal jaren voltijdwerk & 0,057 &, 000 & 0,019 &, 000 \\
\hline Aantal jaren deeltijdwerk & $-0,061$ &, 000 & $-0,508 * * *$ &, $000 * * *$ \\
\hline Aantal jaren zelfstandig & 0,005 &, 000 & $0,048 *$ &, $000 *$ \\
\hline Aantal baanveranderingen & $0,252 * * * *$ &, $000 * *$ & $-0,130$ &, 000 \\
\hline $\begin{array}{l}\text { Neerwaartse mobiliteit (tussen } 40-50 \\
\text { jaar) }\end{array}$ & $-2,688 * * *$ &,$- 002 * * *$ & $-1,516 *$ &,$- 001 *$ \\
\hline Opwaartse mobiliteit (tussen $40-50$ jaar) & $2,924 * * * *$ &, $002 * * *$ & $1,67 \mid * * *$ &, $001 * *$ \\
\hline Urenvermindering (tussen $40-50$ jaar) & $-0,936 \sim$ &,$- 001 \sim$ & $-4,994 * * *$ &,$- 002 * * *$ \\
\hline Urenvermeerdering (tussen $40-50$ jaar) & $-0,230$ &, 000 & $2,832 * * *$ &, $001 * * *$ \\
\hline $\begin{array}{l}\text { Aantal keer werkloos en arbeidsonge- } \\
\text { schikt }\end{array}$ & $-1,512 *$ &,$- 001 *$ & $-1,827 *$ &,$- 001 *$ \\
\hline \multicolumn{5}{|l|}{ Opleidingsniveau } \\
\hline Primair & $-0,782 \sim$ &, $000 \sim$ & 0,322 &, 000 \\
\hline Lager secundair & $-0,368$ &, 000 & $-0,410$ &, 000 \\
\hline Hoger secundair & $-0,104$ & ,900 & $-0,510$ &, 000 \\
\hline Tertiair & ref. & ref. & ref. & ref. \\
\hline Leeftijd & $-0,094 *$ &, $000 *$ & $-0,068$ &, 000 \\
\hline Werkloosheidspercentage & $-0,126 \sim$ &, $000 \sim$ & $-0,076$ &, 000 \\
\hline \multicolumn{5}{|l|}{ Arbeidsdeelname partner } \\
\hline Partner werkzaam & ref. & ref. & ref. & ref. \\
\hline Partner niet werkzaam & 0,283 &, 000 & $0,734 *$ &, $000 *$ \\
\hline Geen partner & 0,394 &, 000 & $-0,547$ &, 000 \\
\hline Intercept & $-20,442 * * *$ & & $-10,037 * *$ & \\
\hline Pseudo $\mathrm{R}^{2}$ &, 273 & &, 436 & \\
\hline$N_{\text {respondenten }}$ & 1.663 & & 1.662 & \\
\hline $\mathrm{N}_{\text {maanden }}$ & |35.487 & & 132400 & \\
\hline
\end{tabular}

Bron: FNB 1998, 2000, 2003 en 2009; p<,I0; * $p<, 05 ; * * p<, 01 ; * * * p<, 001$ 
Het arbeidsverleden van oudere mannen speelt ook een belangrijke rol in het verklaren van hun kans op neerwaartse beroepsmobiliteit en een urenvermindering. Hoe hoger de gemiddelde beroepsstatus vóór de leeftijd van 50 jaar, hoe groter de kans dat mannen ná de leeftijd van 50 jaar neerwaarts mobiel zijn en minder uren gaan werken. Hoe vaker men werkloos en arbeidsongeschikt is geweest in het verleden, hoe kleiner daarentegen de kans op beide uitkomsten. Ook eerdere mobiliteitservaringen (zowel op- als neerwaarts) zijn van belang in het voorspellen van beide gebeurtenissen.

Opleidingsniveau blijkt niet tot nauwelijks van invloed, maar de arbeidsdeelname van de partner wel. Oudere mannen met een partner die inactief is op de arbeidsmarkt hebben meer kans om een dag minder te gaan werken per week dan oudere mannen met een partner die werkzaam is. Tot slot merken we op dat de opgenomen variabelen tezamen goed in staat zijn om verschillen tussen oudere mannen te verklaren in het meemaken van neerwaartse beroepsmobiliteit en arbeidsduurvermindering. De verklaarde variantie (Pseudo $\mathrm{R}^{2}$ ) bedraagt respectievelijk $27,3 \%$ en $43,6 \%$.

\section{Conclusie en discussie}

In veel Europese landen, en ook in Nederland, richt het overheidsbeleid zich tegenwoordig op het langer laten doorwerken van ouderen (Foster \& Walker, 2015). Het is echter de vraag welke oudere werknemers in staat zijn om langer actief te blijven op de arbeidsmarkt en in hoeverre dit sociale ongelijkheid in de hand werkt (Anxo et al., 2012). Eerder onderzoek heeft aangetoond dat lagere sociale klassen vaker onvrijwillig vroegtijdig uittreden (Visser et al., 2016), maar er is nauwelijks onderzoek verricht naar arbeidsmarktervaringen voordat ouderen met pensioen gaan. In deze studie hebben we daarom gekeken naar neerwaartse beroepsmobiliteit en arbeidsduurvermindering onder oudere mannen in Nederland. Werknemers kunnen enerzijds gedwongen worden een stapje terug te doen op latere leeftijd. Anderzijds kunnen oudere werknemers zelf een voorkeur hebben om het rustiger aan te doen. Dit kan onder meer door terug te gaan naar een lagere en minder veeleisende functie of door een dagje minder te gaan werken. We waren voornamelijk geïnteresseerd in de vraag in hoeverre er sociale ongelijkheid bestaat in de kans op het meemaken van beide gebeurtenissen in de late beroepsloopbaan. Daartoe hebben we gebruikgemaakt van retrospectieve loopbaangegevens afkomstig van vier jaargangen van de Familie-enquête Nederlandse Bevolking (FNB). Dit stelde ons in staat om met behulp van een gebeurtenissenanalyse de invloed van sociale klasse op de kans op neerwaartse beroepsberoepsmobiliteit en een urenvermindering te bepalen.

Afgeleid uit veelgebruikte arbeidsmarkttheorieën, te weten de menselijk kapitaal(Becker, 1964), signalerings- (Spence, 1973) en arbeidsmarktsegmentatietheorie (Piore, 1975), luidde onze hypothese dat oudere werknemers in lagere sociale klassen vaker neerwaarts mobiel zijn in termen van beroepsstatus en tevens vaker een urenvermindering meemaken dan oudere werknemers in hogere sociale klassen. De resultaten waren sterk in lijn met deze verwachting en bevestigen derhalve de gangbare arbeidsmarkttheorieën. Theoretisch verwachtten we dat oudere werknemers die tot lagere sociale klassen behoren, door werkgevers als 
minder productief worden beschouwd, een negatief signaal afgeven aan werkgevers en werkzaam zijn in relatief slechtere banen in het secundaire segment van de arbeidsmarkt. Dit zorgt voor een verhoogde kans op zowel vrijwillige als onvrijwillige veranderingen in beroepsstatus en werkuren. Hierbij is belangrijk om uit te lichten dat we een sterke invloed van sociale klasse op beide gebeurtenissen in de late beroepscarrière vinden, zelfs wanneer we rekening houden met opleidingsniveau, arbeidsverleden, partnerkenmerken en macro-economische omstandigheden. Dit duidt op sociale ongelijkheid onder oudere werknemers in Nederland. Aangezien steeds meer ouderen deel uitmaken van de beroepsbevolking en ook op steeds latere leeftijd uittreden, zal deze sociale ongelijkheid de komende decennia een rol blijven spelen op de Nederlandse arbeidsmarkt wanneer lagere sociale klassen niet ondersteund worden.

Toekomstige studies zouden directer kunnen onderzoeken hoe de acties en standpunten van werkgevers ten opzichte van hun oudere werknemers van invloed zijn op neerwaartse beroepsmobiliteit en arbeidsduurvermindering. Deze studies doen er dan goed aan om metingen te gebruiken die dichter bij de veronderstelde theoretische argumenten staan. Te denken valt aan autonomie, baantevredenheid, gezondheid, motivatie en productiviteit. Hoewel sociale klasse een belangrijk kenmerk is in het verklaren van zowel neerwaartse beroepsmobiliteit als urenverminderingen, hadden we graag de beschikking gehad over informatie over de daadwerkelijke redenen waarom oudere werknemers een stapje terug doen in termen van beroepsstatus en werkuren, bijvoorbeeld of het een vrijwillig of onvrijwillig karakter betreft. Dit zou een strengere toets opleveren van de hier gebruikte arbeidsmarkttheorieën.

Verschillen tussen bedrijfstakken of sectoren kunnen ook relevant zijn voor vervolgstudies. De cao's wijken sterk af per sector en daarmee ook de bescherming die oudere werknemers in verschillende sociale klassen en sectoren genieten. De bevindingen met betrekking tot sociale klasse in deze studie suggereren ook dat de sector van belang is. Vergeleken met ouderen in de hoogste sociale klasse (hogere leidinggevenden en academici) hebben (ongeschoolde) handarbeiders de grootste kans op neerwaartse beroepsmobiliteit en een urenvermindering. Zij zijn meestal werkzaam in de industriesector, waarin banen verdwijnen en de arbeidsvoorwaarden minder gunstig zijn. Maar de bevindingen suggereren ook dat er relevante verschillen bestaan tussen bijvoorbeeld ouderen die hogere en lagere posities innemen binnen de dienstensector. Ondanks deze beperkingen tonen de resultaten duidelijk aan dat sociale klasse een sterke invloed uitoefent op de kans dat oudere werknemers neerwaartse beroepsmobiliteit en een urenvermindering meemaken.

Veel werkgevers lijken meer geïnteresseerd in beleid dat oudere werknemers ontziet in plaats van beleid dat ouderen activeert en stimuleert (Conen et al., 2011). De weinig beschikbare studies naar demotie hebben aangetoond dat baantevredenheid afneemt na demotie (Josten en Schalk, 2016), wat aangeeft dat overheden en ondernemingen meer aandacht dienen te besteden aan praktijken die de inzetbaarheid van oudere werknemers verbetert en waarborgt. Het aanbieden van cursussen en trainingen kan bijvoorbeeld een manier zijn om de motivatie en productiviteit van oudere werknemers te verhogen. Uit eerder onderzoek blijkt evenwel dat managers in eerste instantie vooral opleidingsactiviteiten aanbieden aan oudere werknemers die al zeer gemotiveerd zijn en die 
al over meer menselijk kapitaal beschikken, en niet zozeer aan oudere werknemers die het meest gebaat zouden zijn bij dergelijke activiteiten (Karpinska et al., 2015). Een recente studie heeft laten zien dat organisatiebeleid dat zich niet specifiek richt op bepaalde leeftijdsgroepen en voor alle werknemers binnen een onderneming geldt, potentie toont om te kunnen omgaan met een vergrijzende beroepsbevolking (Moen et al., 2016). Daarentegen kan beleid dat oudere werknemers ontziet, negatieve gevolgen hebben voor oudere werknemers in lagere sociale klassen, waardoor de sociale ongelijkheid tussen ouderen kan toenemen.

\section{Noten}

1 Tevens beschikken we niet over longitudinale inkomensgegevens, zodat we niet in staat zijn om vast te stellen of neerwaartse beroepsmobiliteit daadwerkelijk gepaard gaat met een loonsverlaging.

2 We hebben de analyses ook uitgevoerd zonder zelfstandigen. De effecten en conclusies veranderen hierdoor niet tot nauwelijks. Sterker nog: de effecten worden eerder sterker als zelfstandigen niet worden meegenomen in de analyse.

3 Voor neerwaartse beroepsmobiliteit hebben we ook andere coderingen geanalyseerd. Zo hebben we ook gekeken naar een daling van 10 punten, $50 \%$ en $10 \%$ op de ISEIschaal. De correlaties tussen de verschillende metingen variëren van 0,884 tot 0,952 en de resultaten van de gebeurtenissenanalyse zijn dan ook bijna identiek. Met betrekking tot een urenvermindering hebben we ook gekeken naar een daling van 4 uur per week. De resultaten van deze analyse wijken wel licht af van de hier gepresenteerde bevindingen. Het meest opvallende verschil is dat sociale klasse minder van belang is wanneer we kijken naar een daling van 4 uur per week. De schattingen zijn opvraagbaar bij de eerste auteur.

4 Aangezien de geobserveerde persoon-maanden niet onafhankelijk zijn, is het raadzaam om deze afhankelijkheid tussen persoon-maanden van dezelfde persoon te analyseren met behulp van multi-levelanalyse. Deze modellen convergeren echter niet, omdat het aantal gebeurtenissen en met name het aantal herhaalde gebeurtenissen te gering is. Dit leidt tot de situatie dat er geen variatie is op het hogere niveau (in dit geval het persoonsniveau).

\section{Literatuur}

Anxo, D., Ericson, T. \& Jolivet, A. (2012). Working longer in European countries: Underestimated and unexpected effects. International Journal of Manpower, 33, 612628.

Becker, G.S. (1964). Human capital. New York: National Bureau of Economic Research.

Blossfeld, H.-P., Buchholz, S. \& Kurz, K. (2011). Aging populations, globalization and the labor market: Comparing late working life and retirement in modern societies. Cheltenham: Edward Elgar.

Carson, P.P. \& Carson, K.D. (2007). Demystifying demotion: A look at the psychological and economic consequences on the demotee. Business Horizons, 50, 455-466.

CBS (2016). StatLine database. Te bereiken via: http://statline.cbs.nl

Conen, W.S., Henkens, K. \& Schippers, J. (2011). Are employers changing their behavior toward older workers? An analysis of employers' surveys 2000-2009. Journal of Aging \& Social Policy, 23, 141-158.

Conen, W.S., Henkens, K. \& Schippers, J. (2012). Employers' attitudes and actions towards the extension of working lives in Europe. International Journal of Manpower, 33, 648665.

Dalen, H.P. van \& Henkens, K. (2013). Waarom leidinggevenden zich niet branden aan demotie. Me Judice, 30 oktober 2013. 
Dalen, H.P. van \& Henkens, K. (2014). De redelijkheid en waarschijnlijkheid van demotie. Economisch Statistische Berichten, 99, 708-711.

Dalen, H.P. van \& Henkens, K. (2015). Is demotie echt een taboe? Oudere werknemers aan het woord. Me Judice, 16 oktober 2015.

Dalen, H.P. van, Henkens, K. \& Schippers, J. (2009). Dealing with an ageing labor force: What do European employers expect and do? Journal of European Social Policy, 19, 47-60.

Dalen, H.P. van, Henkens, K. \& Schippers, J. (2010a). How do employers cope with an ageing workforce? Views from employers and employees. Demographic Research, 22, 1015-1036.

Dalen, H.P. van, Henkens, K. \& Schippers, J. (2010b). Productivity of older workers: Perceptions of employers and employees. Population and Development Review, 36, 309330.

Deaton, A.S. \& Paxson, C.H. (1998). Aging and inequality in health and income. American Economic Review, 88, 248-253.

Ebbinghaus, B. \& Radl, J. (2015). Pushed out prematurely? Comparing objectively forced exits and subjective assessments of involuntary retirement across Europe. Research in Social Stratification and Mobility, 41, 113-128.

Erikson, R. \& Goldthorpe, J.H. (1992). The constant flux: A study of class mobility in industrial societies. Oxford: Oxford University Press.

Foster, L. \& Walker, A. (2015). Active and successful aging: A European policy perspective. The Gerontologist, 55, 83-90.

Ganzeboom, H.B.G., Graaf, P.M. de \& Treiman, D.J. (1992). A standard International Socio-Economic Index of occupational status. Social Science Research, 21, 1-56.

Gesthuizen, M. (2009). Job characteristics and voluntary mobility in the Netherlands: Differential education and gender patterns? International Journal of Manpower, 30, 549-566.

Gesthuizen, M. \& Dagevos, J. (2008). Mismatching of persons and jobs in the Netherlands: Consequences for the returns to mobility. Work, Employment and Society, 22, 485-506.

Gesthuizen, M. \& Verbakel, E. (2011). Job preferences in Europe: Tests for scale invariance and examining cross-national variation using EVS. European Societies, 13, 663-686.

Groot, W. (1997). Demotie demotiveert. Economisch Statistische Berichten, 82, 820-822.

Jongsma, R. (2014). Demotie: Het laatste taboe doorbroken. Alphen aan den Rijn: Vakmedianet.

Josten, E.J.C. \& Schalk, R. (2010). The effects of demotion on older and younger employees. Personnel Review, 39, 195-209.

Josten, E.J.C. \& Schalk, R. (2016). Wat zijn de effecten van demotie? Een update van onderzoek. Tijdschrift voor HRM, 1-15.

Kalleberg, A.L., Reskin, B.F. \& Hudson, K. (2000). Bad jobs in America: Standard and nonstandard employment relations and job quality in the United States. American Sociological Review, 65, 256-278.

Karpinska, K., Henkens, K., Schippers, J. \& Wang, M. (2015). Training opportunities for older workers in the Netherlands: A vignette study. Research in Social Stratification and Mobility, 41, 103-112.

Kraaykamp, G., Wolbers, M.H.J. \& Ruiter, S. (2009). Familie-enquête Nederlandse Bevolking 2009 (dataset). Radboud Universiteit Nijmegen: Sectie Sociologie.

Lazear, E.P. (1979). Why is there mandatory retirement? Journal of Political Economy, 87, 1261-1274.

Moen, P., Kojola, E. \& Schaefers, K. (2016). Organizational change around an older workforce. The Gerontologist. doi:10.1093/geront/gnw048

Oude Mulders, J., Henkens, K. \& Schippers, J. (2015). Organizations' ways of employing early retirees: The role of age-based HR policies. The Gerontologist, 55, 374-383.

Piore, M. (1975). Notes for a theory of labor market stratification. In R. Edwards, M. Reich \& D. Gordon (eds.), Labor market segmentation (pp. 125-150). London: Lexington Books.

Radl, J. (2013). Labor market exit and social stratification in Western Europe: The effects of social class and gender on the timing of retirement. European Sociological Review, 29, 654-668. 
SCP. (2015). Vraag naar arbeid 2015. Den Haag: Sociaal en Cultureel Planbureau.

Smits, J.M.P., Beeksma, M., Feenstra, P.W. \& Junger-van Hoorn, E.C. (2010). Perspectief op langer doorwerken: Een onderzoek naar cao-afspraken tussen sociale partners met betrekking tot langer doorwerken. Den Haag: Ministerie van Sociale Zaken en Werkgelegenheid.

Sørensen, A.B. (1975). The structure of intragenerational mobility. American Sociological Review, 40, 456-471.

Spence, M. (1973). Job market signaling. Quarterly Journal of Economics, 87, 355-374.

Tilly, C. (1996). Half a job: Bad and good part-time jobs in a changing labor market. Philadelphia: Temple University Press.

Visser, M. (2017). Inequality between older workers and older couples in the Netherlands: A dynamic life course perspective on educational and social class differences in the late career. Nijmegen: ICS-dissertation.

Visser, M., Gesthuizen, M., Kraaykamp, G. \& Wolbers, M.H.J. (2016). Inequality among older workers in the Netherlands: A life course and social stratification perspective on early retirement. European Sociological Review, 32, 370-382. 